\title{
VARIETIES OF CAPITALISM, CORPORATE GOVERNANCE MECHANISMS, AND STAKEHOLDER ENGAGEMENT: AN OVERVIEW OF COORDINATED AND LIBERAL MARKET ECONOMIES
}

\author{
María Consuelo Pucheta-Martínez ${ }^{1}$ \\ Isabel Gallego-Álvarez ${ }^{2}$ \\ Inmaculada Bel-Oms ${ }^{3}$
}

\footnotetext{
${ }^{1}$ Departamento de Finanzas y Contabilidad, Universidad Jaume I, Castellón, Spain

${ }^{2}$ Departamento de Administración y Economía de la Empresa, Universidad de Salamanca and Instituto Multidisciplinar de Empresa (IME), Salamanca, Spain

${ }^{3}$ Departamento de Finanzas Empresariales, Universidad de Valencia, Valencia, Spain
}

Correspondence: María Consuelo Pucheta-Martínez, Associate Professor, Departamento de Finanzas y Contabilidad, Universidad Jaume I, Campus del Riu Sec, s/n, Castellón 12071, Spain. Email: pucheta@uji.es

\section{ACKNOWLEDGEMENTS}

The authors acknowledge financial support from the Spanish Ministry of Economy, Industry and Competitiveness for the research project ECO 2017-82259-R and from the University Jaume I for the research project UJI-B2018-15. 


\title{
VARIETIES OF CAPITALISM AND CORPORATE GOVERNANCE MECHANISMS: AN OVERVIEW OF COORDINATED AND LIBERAL MARKET ECONOMIES
}

\begin{abstract}
This paper examines those aspects of national institutions that affect corporate governance mechanisms at international level. The study uses the "varieties of capitalism" approach proposed by Hall and Soskice (2001), and Hall and Gingerich (2009). This approach is concerned with the way companies interact strategically to solve the coordination problems arising from their activities. This research is based on a sample of countries operating in coordinated market economies (CMEs) and liberal market economies (LMEs). The data were collected from the Thomson Reuters database. The findings suggest that the institutional context is associated with several corporate governance mechanisms. Specifically, our results find that the proportion of female directors on boards and the presence of corporate governance committees are higher in firms operating in LMEs than in those domiciled in CMEs. Regarding the disclosure of corporate social responsibility information, the evidence shows that it is not affected by the varieties of capitalism measured, while board-specific skills are higher in the latter than in the former. This paper offers empirical evidence at international level for the varieties of capitalism that contribute to better corporate governance structures. With regard to managerial implications, our findings show that belonging (or not) to a specific variety of capitalism impacts various mechanisms of corporate governance.
\end{abstract}

Keywords: Varieties of capitalism, CSR disclosure, Boards specific skills, corporate governance committees 


\section{Introduction}

Corporate governance includes the procedures and processes by which organisations are directed and controlled by their CEO, board of directors, and senior management. Previous literature (Jensen, 1993; Shleifer and Vishny, 1997; Bhagat and Bolton, 2008) states that the board of directors is an important and effective internal corporate governance mechanism, fulfilling two important functions within companies: the supervision of executive management on behalf of shareholders, and the provision of business and advisory resources. According to Zheka (2005), corporate governance defines the distribution of rights and responsibilities among the company's different stakeholders, and establishes rules and procedures for decision-making. Furthermore, it provides structures through which the company's objectives are established and supervision is enacted.

Kiel and Nicholson (2003) suggest that although much of the debate on corporate governance and research activity has focused on the United States, in recent years there has been an increase in international publications on corporate governance in different countries, such as New Zealand, Italy, and the UK (Hossain et al., 2001; Bianco and Casavola, 1999; Vafeas and Theodorou, 1998). In addition, corporate governance has been analysed from the perspective of different disciplines, such as economics and management, culture and sociology, and legal and political paradigms (e.g., Jensen and Meckling, 1976, Fama, 1980, Useem, 1984, Johnson et al., 1996), giving rise to numerous governance theories, with the varieties of capitalism being one of them.

For Hall and Gingerich (2009), the theory on varieties of capitalism assumes that companies are the main protagonists of an economy, whose activity is included within national economic performance. In order to prosper, companies must engage with other players at numerous levels of economic policy. In this sense, Aguilera and Jackson (2003) propose a comparative corporate governance model, which suggests that liberal market economies (LMEs) differ from coordinated market economies (CMEs) in terms of stakeholder salience, emphasising the need to incorporate institutional dimensions into the corporate governance field.

The varieties of capitalism approach (Hall, 2007; Hall and Soskice, 2001, Soskice, 2007) has been developed in political economics with a view to understanding the institutional similarities and differences across the economies of different countries, at the same time as it places companies at the heart of the analysis. This approach focuses on companies and the manner in which they interact strategically to resolve the coordination issues prompted by their activities. This approach thereby seeks to link micro-level aspects 
related to the rational and strategic behaviour of players and organisations to those at macrolevel related to economic policy and the workings of national institutions. According to Hall and Soskice (2001), the varieties of capitalism are focused on the players' strategic interactions, and the ways in which they are conditioned by the different institutions with which they interact. This approach considers that the different forms adopted by capitalist systems may be differentiated by the manner in which the social partners and institutional systems are structured in each particular context. The different institutional systems are mainly the outcome of political commitments. According to Hartmann and Uhlenbruck (2015), this approach seeks to explain why and how legal, market and social institutions shape companies' behaviour and performance. Whenever governments differ in their policies on these issues, we may therefore expect that this will probably lead to differences in firm performance.

In short, we may establish that varieties of capitalism divide some advanced economies into liberal and coordinated market economies, based on the allocative mechanism of resources, profits and risk. Coordinated market economies (CMEs) are focused toward stakeholders, while liberal market economies (LMEs) lean toward shareholders. CMEs involve major state control and are influenced by organisations such as employee associations and labour organisations (Kang and Moon, 2012), whereas LMEs involve countries characterised by a major market prevalence, prioritising the rights of shareholders and lenders, with less emphasis on the role played by other stakeholders (Aguilera and Jackson, 2003).

Considering the above arguments, the aim here is to analyse at international level how aspects of institutional environments are associated with various mechanisms of corporate governance. CMEs and LMEs are similar in some aspects of corporate governance mechanisms, but they also differ in others. This paper therefore focuses on these differences, and we particularly analyse the following corporate governance mechanisms: corporate social responsibility (CSR) disclosure as a dimension of corporate governance, board-specific skills, the number of female directors on corporate boards, and corporate governance committees. As regards CSR disclosure as a dimension of corporate governance, the shareholder and stakeholder orientations are the ones predicting that managers conduct CSR to fulfil their moral, ethical, and social duties to their stakeholders, and strategically achieve corporate objectives for the company's shareholders. As Desender and Epure (2015) argue, in the shareholder model, also referred to as market-oriented, the interactions are transactional in nature. By contrast, the stakeholder-focused system, also referred to as the internal model, is 
based on banks or credit-based financing, and involves debt financing and closely interconnected relational networks across companies, their trading partners, and financial institutions. In this regard, we predict that CSR disclosure will be different between CMEs and LMEs because the former focus more on stakeholders and the latter do so more on shareholders.

Regarding board-specific skills, the nature of the educational system and labour market are the determinants of these skills in the different contextual dimensions of varieties of capitalism. Matten and Moon (2008) therefore contend that Europe and the US differ in those aspects related to human resources in school education and in public policies on training and the labour market. Accordingly, we posit that board-specific skills are a priority in CMEs, because these skills serve industries and companies in the long term.

Regarding the presence of female directors on boards, cultural factors help us to find differences between LMEs and CMEs. Liberal economies (LMEs) will be more inclined to regulate or support the presence of women on corporate boards, as countries within this context are more feminist and open-minded. Mandel and Shalev (2009) therefore indicate that female professionals and managers in LMEs are better able to compete with men for top-tier jobs and generous remuneration than in CMEs. Terjesen and Singh (2008) also affirm that the proportion of female managers has improved over time in LME countries, such as the US and UK. Thus, according to prior research, it seems that LME countries tend to support more board gender diversity than their CME counterparts. The cultural differences between CMEs and LMEs may result in boards with higher or lower percentages of women directors.

As regards corporate governance committees, the laws, recommendations and issues related to corporate governance mechanisms will be more developed in LMEs, where the financing by the capital market prevails. This is because capital markets are financed by different investors, which means companies need to have corporate governance mechanisms in place to safeguard the rights and interests of shareholders and investors. Companies in these economies will be more inclined to implement these corporate governance mechanisms, such as a corporate governance committee, because if they fail to do so they might be penalised by capital markets (Ioannou and Serafeim, 2012; Aguilera and Jackson, 2003). In contrast, CMEs are more bank-oriented systems, and firms usually obtain funds from financial institutions and less so from capital markets. Firms are therefore less exposed to public and market scrutiny, and might feel under less pressure to create corporate governance committees. These differences also lead us to analyse whether it is more likely that corporate governance committees will be introduced in LMEs or in CMEs. 
In this regard, we explain cross-national diversity in corporate governance by specifying and integrating the various institutional mechanisms shaping stakeholders' roles at firm level (Aguilera and Jackson, 2003). Specifically, we consider varieties of capitalism proposed by Hall and Soskice (2001) and Hall and Gingerich (2009).

This paper thus extends the debate outlined above and contributes to the existing literature in several ways. Firstly, it uses an unbalanced panel dataset of 10,043 company-year observations from 16 countries during the period 2004-2015. This is in contrast to previous studies that focus mainly on specific time periods and on a restricted sample of companies operating in specific countries, such as Australia, Japan, and the UK (Kiel and Nicholson, 2003; Ullah, 2017; Weir and Laing, 2001; Chen et al., 2015). Moreover, the availability of data from multiple countries adds special interest to our research because it allows the analysis to be extended to a broader point of reference than the corporate system addressed by most existing studies. Secondly, this research contributes to existing knowledge on the influence of different institutional contexts according to the following corporate governance attributes: CSR disclosure as a dimension of corporate governance, board-specific skills, female directors on corporate boards, and corporate governance committees. Thus, our reference involves those perspectives on varieties of capitalism not often considered in previous research (Hall and Soskice, 2001; Jackson and Apostolakou, 2010). This explains the variations and changes that exist within capitalist systems through a broad dichotomy of institutional contexts in both liberal and coordinated economies. Thirdly, our evidence shows that in contrast to past research, the likelihood of disclosing CSR information is the same in CMEs and LMEs. It was expected to be higher in CMEs than in LMEs, but the findings report that CSR reporting is not affected by the varieties of capitalism involved. Fourthly, our results support the paper's initial thesis whereby companies belonging to a specific context are homogeneous and adopt the same model of corporate governance. This evidence may be due to the fact that we analyse different aspects of corporate governance within the framework of varieties of capitalism, as Hall and Gingerich (2009) suggest that the organisations operating under the same institutional environment are pressured to behave similarly. This leads companies (belonging to a specific context) to become homogeneous and adopt the same model of corporate governance. Finally, the further contribution to past empirical evidence involves using board-specific skills as a dependent variable. To our knowledge, no preceding research has analysed this variable within the framework of varieties of capitalism.

The paper is structured as follows. Following this introduction, the theoretical framework and hypotheses are provided in the second section. The empirical design is 
presented in the third section, where the sample and variables are described. Our findings are analysed in the fourth section. The discussion is presented in the fifth section, drawing the conclusions and implications derived from our analysis.

\section{Theoretical framework and research hypotheses}

Varieties of capitalism theory assumes that companies are the economy's main players, with their performance going hand-in-hand with the country's overall economic performance. In order to prosper, companies need to engage with other players in multiple spheres of economic policies (Hall and Gingerich, 2009). The varieties of capitalism perspective was developed at the end of the 1990s within the field of political economics to compare economies of different countries, whilst simultaneously placing companies at the heart of the analysis. This perspective is mainly concerned with analysing how companies behave and interact within a particular institutional structure (Hall, 2007; Hall and Soskice, 2001; Soskice, 2007). This theory is therefore closely aligned with companies and how they interact strategically to solve the coordination problems that emerge because of their activities. According to Hall and Soskice (2006), the actions of organisations are defined by their relationships with other players, generating stable patterns that make up a certain political economy or variety of capitalism. It is important to note that the term player is used to refer to individuals, groups, and organisations that interact to produce certain results. In this regard, Amaeshi and Amao (2009, p. 227) consider that 'the varieties of capitalism of comparative business systems, for instance, offer an analytical framework for understanding the political economy of firm's behaviour and performance'.

The main academic emphasis in this field lies in the distinctive nature of national institutional contexts, where companies operate within different spheres and are subject to the influence of other social networks, such as unions and regulatory authorities. Thus, the institutional contexts within the system of varieties of capitalism is focused on CMEs and LMEs (Hall and Soskice, 2001; Vitols, 2001; Hancke et al., 2007; Amable, 2003).

In LMEs, the rights of shareholders and creditors are prioritised over other stakeholders. Furthermore, this type of economy is characterised by market dominance and a notion of ownership rights (Hall and Gingerich, 2009). In CMEs, the government prevails, and the interests of organisations such as business associations and trade unions play an important role (Kang and Moon, 2012). Countries operating in CMEs are socially oriented and focus on satisfying the needs of a wide range of stakeholders, such as employees, suppliers, and shareholders (Dore, 2000; Hall and Gingerich, 2009). 
However, the theory on varieties of capitalism is based on different contextual dimensions: the role of the state in the economy, the type and development of financial markets, and the nature of the educational system and labour market (Whitley, 1999). Regarding the first dimension, the role of the state in the economy, Carney and Witt (2012), Whitley (2005) and Fainshmidt et al. (2018) suggest that the state wields its influence over a country's economy in three different ways: directly, as it is actively and directly involved in economic output through state-owned companies, indirectly, through the provision of capital, favouritism, or involvement in corporate governance, and through the general approach it adopts toward the nation's economic life. Regarding the different models of state, we may highlight the LME and CME countries under study here. On the one hand, the regulatory state is responsible for drafting and laying down the rules of the game and, in particular, the protection of ownership rights, with the US being a clear example of an LME country. Another type of economy would be the welfare state, where more importance is given to the protection and promotion of its citizens' economic and social wellbeing, mainly through the state's redistribution of wealth (Northern European countries are typical examples of CMEs).

Regarding the second dimension, which refers to the role of financial markets, capital providers are key players for organisations, as they finance commercial operations (Freeman et al., 2007) and investment, and therefore have an impact on firms' development and survival. In some LME countries, such as the US, the financial system is based on the capital market, which is the main source of funding for firms. This is because firms obtain their capital from the corresponding stock market, and the investment is relatively dispersed among shareholders. Firms therefore have to ensure a high degree of transparency and accountability for investors (Ioannou and Serafeim, 2012; Aguilera and Jackson, 2003). Another arrangement is the credit-based or bank-based financial system. A bank-based financial system is one in which financial institutions are crucial for marshalling household deposits and channelling them directly into business loans (e.g., Germany and France are CME countries). Besides the close ties between banks and industrial corporations, these systems tend to have small and weakly developed capital markets that make firms more dependent on borrowing. Financing through bank loans involves both a strict supervision of capital and contingency planning, which leads to long-term capital commitment. This therefore means that "financial systems influence corporate governance through their capacity to provide different sources of capital and to affect the relationship with the firm" (Aguilera and Jackson, 2003, 454). 
Anther contextual dimension that differs between an LME and a CME is the nature of the educational system and labour market. Matten and Moon (2008) contend that Europe and the US differ in those aspects related to human resources in school education. Moreover, they affirm that public policies on training and the labour market have been put in place in Europe in which organisations have taken part according to the different regulations and customs that exist, whereas in the US it has been an area in which companies themselves have developed their own strategies. At the same time, European organisations have shown a greater propensity to pursue collective interests through national business associations or federations. This associative power can therefore exert pressure to obtain greater benefits for employees, focusing more on health and safety provisions, progressive policies in industrial relations, and more workplace services, and may lobby for greater community involvement. This labour strength may even raise general awareness within society by acting as an ambassador for a firm's environmental and social policies. Thus, as Hall and Gingerich (2009) demonstrate, when labour relations are based on strong unions and coordinated wage negotiations, it is more efficient for companies to operate collaborative training schemes that confer a high level of industry-specific skills. In sum, the level of the labour market within a national context is important because it determines how organizations engage with employees in productive activities. For instance, when knowledge capital is collectively available to firms within an economy, organisations may invest in firm-specific skills (Aguilera and Jackson, 2003), whereas a scarcity of knowledge capital may reduce incentives to invest in particular capabilities and even sectors.

Besides the above aspects, the shareholder and stakeholder orientations should be considered within our theoretical frameworks, for as Desender and Epure (2015) posit, in the shareholder model (LME), also referred to as market-oriented, interactions are transactional in nature. This model is based on the market's strength for the proper allocation of resources within firms, and is based on extremely powerful incentives and external control systems for supervising managers and aligning their interests. According to Kang and Moon (2012), companies identified by this variety of capitalism focus on the interests of investors and managers as key players. By contrast, the system focusing on stakeholders (CME), also referred to as the internal, bank-based or credit-based financial model, involves debt financing and closely interconnected relational networks across companies, trade partners and financial institutions. Moreover, as Kang and Moon (2012) suggest, it is important for companies and economic agents in CMEs to maintain social cohesion, with labour and employee rights being a priority 
Within this conceptual framework of varieties of capitalism, considering different institutional contexts and the shareholder and stakeholder orientations, this study explores whether operating in either an LME or a CME country has an impact on a company's implementation of the following corporate governance mechanisms: CSR disclosure, boardspecific skills, female directors on boards, and corporate governance committees.

\subsection{CSR disclosure}

According to Jamali (2006), CSR is a concept that attracts worldwide attention, acquiring new resonance in the global market. Regarding its relationship with corporate governance, Jamali et al. (2008, p. 447) suggest three models that postulate a relationship between corporate governance and CSR: (1) corporate governance as a pillar for CSR, (2) CSR as a dimension of corporate governance, and (3) corporate governance and CSR as part of a continuum. For the purpose of this research, we draw upon the second model proposed (CSR as a dimension of corporate governance), because the objective is to analyse various corporate governance mechanisms, and CSR can be considered one of them. In addition, as indicated by Jensen (2002) and Aguilera et al. (2007), both corporate governance and CSR are manifestations of companies' fiduciary and moral responsibilities towards stakeholders. Managers' attitudes toward CSR practices may be affected by a country's shareholder or stakeholder orientation. Managers interested in showing their ethical, moral and social duties toward their stakeholders will be more likely to engage with CSR matters, in line with countries where stakeholder orientation prevails. However, this commitment to CSR policies will be lower if managers are willing to fulfil more shareholder aims and needs than stakeholder demands, consistent with contexts with a higher shareholder orientation. LME countries are more oriented toward shareholders (market-oriented model) and the interactions are transactional in nature (Desender and Epure, 2015). By contrast, CME contexts are oriented toward stakeholders and are based on the credit-based model and involve debt financing.

Using the framework of varieties of capitalism, various studies have focused on analysing how CMEs and LMEs influence CSR disclosure. Authors such as Kang and Moon (2012) suggest that it is important for companies and economic agents in CMEs to maintain social cohesion — with labour and employee rights being a priority-with strong pressure to perform CSR practices (Aguilera et al., 2007; Campbell, 2007). Consequently, CSR disclosure aims to maintain the social order or the status quo necessary to sustain the business by establishing relationships among different stakeholders (Brammer et al., 2012; Favotto et 
al., 2016). Therefore, in CMEs, companies use CSR disclosure as a form of dialogue with stakeholders, and include stakeholders in the process of obtaining and communicating information. In sum, CMEs recognise that stakeholders play an important role. Moreover, as Kang and Moon (2012) state, in CMEs priority is given to essential issues such as economic development, frequently related to labour issues.

In contrast, LMEs are traditionally characterised by a market-based economy with corporate responsibility oriented primarily towards shareholders (Vitols, 2001). In these countries, the financial system (based on the stock market) and labour relations (based on contracts) create a national system of corporate governance characterised by the value of the shareholders (Vitols, 2001). In LMEs, management is particularly sensitive to the demands of shareholders, given the strong dependence on the stock market as a means of financing business. Therefore, the value of shareholders increasingly replaces the public value of companies, and many governance mechanisms depend on the market. In addition, such countries come under the common law classification made by La Porta et al. (1998), and focus on shareholder protection and creditor rights, while giving less importance to the role of other stakeholder groups. According to Kang and Moon (2012), companies identified by this variety of capitalism focus on the interests of investors and managers as key players.

Aguilera and Jackson (2003) suggest that trade or employee associations and institutionalised dialogue with stakeholders lead to greater emphasis on the presentation of CSR disclosure. In addition, according to Campbell (2007), companies are more likely to adopt socially responsible practices if they participate in a dialogue with employees, unions, communities, investors, and other stakeholders in the company.

Therefore, according to the above arguments, the following hypothesis is proposed:

Hypothesis 1: CSR disclosure is higher in coordinated market economies than in liberal market economies.

\subsection{Board-specific skills}

According to Hillman et al. (2000), the term board-specific skills refers to board members who have an industry-specific background and are considered business experts. Thus, business experts are those board members who have knowledge based on their previous experience and are more effective, providing companies with resources in the form of skills, knowledge, experience, legitimacy, reputation, and the ability to achieve commitment and links between companies and stakeholders (Pfeffer and Salancik, 1978). According to Wincent et al. (2010) and Johnson et al. (2013), this human and social capital comes from education, knowledge, and the experience acquired by these directors outside the company, 
Finegold and Soskice (1988) state that when considering different institutional contexts of varieties of capitalism, there are significant differences in economies that can influence business experts and, therefore, also the board members of the different companies belonging to these institutional contexts. Thus, and according to Matten and Moon (2008), the labour market and the nature of the educational system describe board-specific skills in the different contextual dimensions of varieties of capitalism. Matten and Moon (2008) also identify systems for developing and supervising board-specific skills: the education system is the one that develops and certifies competencies and skills, and the labour market involves the institutions that control the terms under which these markets are organised. Along these same lines, these authors identify different aspects related to human resources in education and in the public policies on training and the labour market that make Europe and the US different. For example, higher levels of membership of labour organisations in Europe (mostly CME countries) than in the US (LME country) which is to the advantage of employees. Furthermore, CME countries consider skills to be assets that are invested and used by multiple players, such as business associations and labour organisations that belong to many different economic sectors.

According to Hall and Soskice (2003), there are differences between the educational systems of both LMEs and CMEs. In general terms, these differences can be summarised thus: in LMEs, most training and development initiatives at various levels are designed to develop general skills, while company specific skills are in greater demand in CMEs. More specifically, in LME countries (e.g., the United States) the nature of the labour force is subject to a high turnover, and companies are more likely to hesitate to commit to a higher level of expenditure for recruitment, development, and training purposes. This is because companies in such countries fear training their workforce, as they will leave their jobs for competitor companies in search of better opportunities. Consequently, educational institutions in these countries organise courses that offer more generic skills that can be applied to a wide range of industries and companies.

By contrast, the development of company-specific skills is a priority in CMEs, because these skills serve industries and companies in the long term. Thus, as Hall and Gingerich (2009) shoe, when labour relations are based on strong unions and coordinated wage negotiations, it is more efficient for companies to operate collaborative training schemes that confer a high level of industry-specific skills. The high wages established at industry level encourage workers to acquire certain skills specific to each industry. This makes it more difficult for less-prepared companies to hire workers from other companies by offering them 
premium salaries. This in turn encourages workers to remain in the same workplace for longer periods of time (Bosch and Charest, 2008). As indicated, it seems that in CMEs there are more specific skills programmes targeting the labour market than in LMEs and-by extension-board members in CMEs are more likely to have specific skills, such as industryspecific skills.

Hence, these arguments lead us to propose the following hypothesis:

Hypothesis 2: Board-specific skills are higher in countries domiciled in coordinated market economies than in liberal market economies.

\subsection{Female directors on corporate boards}

There is an increasing number of studies analysing the relevance of female board directors. This is because it has been demonstrated that their presence can improve financial reporting quality, and the promotion of good business practices and strategic decisions for companies (Pucheta-Martínez et al., 2016; Rogelberg and Rumery, 1996).

In the context of varieties of capitalism, it is necessary to explore the influence that this economic system may have on the presence of women on boards because it can differ depending on whether a company is located in a CME country or an LME country. Further, it should be taken into account that each one presents different peculiarities. In this regard, considering more liberal mindsets, cultural factors, and bearing in mind the role of women in society, it is more likely to find women directors on boards in LME contexts. Past research (Terjesen and Singh, 2008) shows that LME countries such as the UK and the US have increased the number of women managers in firms in recent years within the framework of the varieties of capitalism. This may also be due to the scandals over corporate governance triggered by Enron, WorldCom and Parmalat, which have led to a new set of regulations (e.g., the Sarbanes-Oxley Act; the Combined Code) in relation to corporate board structures, processes, duties and responsibility, including the recommendation to have more women on boards. There are cultural and legal differences between LMEs and CMEs, which might alter the presence of female directors on boards in one or other type of countries, with a higher presence to be expected in LMEs than in CMEs.

According to Hall and Soskice (2001), examples of countries with CMEs include Germany, Switzerland, and Belgium. In these countries, most companies offer training programmes in order to provide skills to workers and guarantee them specific positions (Dore, 2000; Hall and Gingerich, 2009). Therefore, these countries are characterised by strong labour relations, broad professional training, and solid business networks. Authors such as Estevez- 
Abe $(2005,2006)$ consider that these characteristics of CMEs do not contribute to the ambitions that women may have in management positions, in particular because of the close relationship between companies and workers through the professional training that workers receive, or due to their unemployment benefits. All this makes investment in specific skills more feasible than in other countries such as the US, the UK and Australia-countries that Hall and Soskice (2001) denote as LMEs. In these countries, the market plays a decisive role in the balance of labour relations, trade is based mainly on contracts, and extensive collaborations within the industry are replaced by competition. In addition, business associations in these countries are weak, and companies lack the capacity to develop training programmes in order to provide workers with specific skills. Therefore, the acquisition of skills by workers is more general.

Mandel and Shalev (2009) claim that the variety of capitalism perspective is more suitable for more clearly understanding the position of women directors in LMEs. In this kind of liberal economy, neutral positions tend to be adopted in regard to both gender roles in the labour market, and the division of responsibilities in relation to the work-family dichotomy. In this type of countries, women are freer to compete with men for the highest positions. According to Mandel and Semyonov (2006), prior evidence on the success of women in senior positions shows that the progress of women (in both management positions and board membership) has been more significant in liberal economies like the US. In this sense, Grosvold and Brammer (2011) consider that there is a higher prevalence of women on boards in LMEs than in other countries, and so based on the above arguments, we propose the following hypothesis:

Hypothesis 3: The proportion of female directors on boards is higher in liberal market economies than in coordinated market economies.

\subsection{Corporate governance committee}

Corporate governance committees are control mechanisms, different from the board of directors. These committees assist boards to carry out their activities in an efficient and independent manner (Harrison, 1987; Tao and Hutchinson, 2013), in such a way that the main decisions taken by the boards of directors are sometimes actually circulated from the corporate governance committees (Andrews, 1997).

According to Harrison (1987), corporate governance committees are mechanisms for monitoring management, protecting the interests of shareholders and, additionally, serve strategic purposes for companies, such as maintaining corporate legitimacy and contributing to the formulation of corporate strategies. However, there may be additional reasons for 
companies to have different committees, such as reducing the workload, or providing various solutions to critical problems (Johanson and Østergren, 2010). Moreover, the most effective use of corporate governance committees can lead to more responsible behaviour by boards and strong protection of shareholder's interests.

In the case of corporate governance committees, companies operating in LMEs (where shareholder protection is important) are more likely to implement such committees. Chizema and Shinozawa (2012) indicate that the existence of committees is common practice in English-speaking countries within their particular style of corporate governance, oriented toward the shareholder value model (Aguilera and Jackson, 2003; Yoshikawa et al., 2007). The importance for companies in these liberal economies (LMEs) of implementing corporate governance mechanisms, such as a corporate governance committee, lies in the fact that if they fail to do so, they run the risk of being penalised by the capital markets (Ioannou and Serafeim, 2012; Aguilera and Jackson, 2003). Companies operating in LME contexts borrow mainly from capital markets, which means the regulators in these companies legislate and recommend in relation to corporate governance mechanisms, as these will enable companies to administer and manage themselves more efficiently. On the other hand, firms domiciled in CME countries operate in bank-oriented systems and, therefore, banks are obviously their main financial source. These differences induce us to consider and analyse whether there a greater likelihood of more corporate governance committees being set up in LME countries than in CME ones.

According to the Cadbury Report (1992), one of the reasons for introducing board committees in English-speaking countries was to reduce the influence executive directors have on decisions, where independence is considered a highly relevant and crucial issue. Another reason for the formation of a committee is that it is considered vital for the board to fulfil its duties (Huang et al., 2012). Thus, according to the above arguments, we propose the following hypothesis:

Hypothesis 4: The presence of corporate governance committees is higher in liberal market economies than in coordinated market economies.

\section{Empirical Design}

\subsection{Sample}

The initial sample for the panel data examination was composed of 13,178 observations collected from 2005 to 2015 (inclusive). All financial companies were excluded from the initial sample because they comply with specific accounting rules, which makes it 
more difficult to compare annual financial statements between non-financial and financial companies. Furthermore, all those companies missing data on some variables were excluded. Thus, the final sample consisted of 10,043 international companies, building an unbalanced panel data sample. Nevertheless, as Arellano (2003) supports, these panels are as trustworthy and consistent as balanced panel data. The Thomson Reuters database was used to provide information on corporate governance, CSR, board attributes, and economic and financial information.

As the study differentiates between LME and CME, companies from 16 countries formed the sample according to this classification. The countries with LMEs were Australia, Canada, Ireland, New Zealand, the UK, and the US, while the CME countries were Austria, Belgium, Denmark, Finland, Germany, Japan, the Netherlands, Norway, Sweden, and Switzerland (Hall and Soskice, 2001).

Table 1 provides the number of observations by country (and their percentages) for the total sample. As is evident, the country with least representation in the sample is Austria (with 34 observations) and the country with the highest is the US (with 3,581).

\section{$<$ Insert Table 1>}

Table 2 illustrates the sector classification used in this analysis, based on the Thomson Reuters Business Classification (TRBC) provided by Thomson Reuters. As is evident from the data in Table 2, the sample comprised nine activity sectors. Companies belonging to the industrial sector represent $21.6 \%$, followed by the consumer cyclical and commodities sectors at $19.90 \%$ and $13.80 \%$, respectively. The sector with the lowest representation was telecommunications services at 3.3\%.

$$
<\text { Insert Table 2> }
$$

\subsection{Dependent variables}

Four different dependent variables were used, based on the corporate governance field. The first dependent variable, CSR disclosure as a dimension of corporate governance (CSR_DISC), was calculated by using a multidimensional construct, which allowed all social and environmental items disclosed by a company to be considered (Rupp and Mallory, 2015). Particularly, an index was constructed by aggregating all the items disclosed by companies on environmental and social matters, out of a total of 112 items analysed. If the company disclosed one item, then a value of 1 is added, and 0 otherwise (Gallego-Álvarez and Ortas, 2017). The environmental items were focused on innovation, resource use, and emissions, while the social items refer to four fields: human rights, product responsibility, workforce, 
and community. The second dependent variable was board-specific skills, denoted by B_SPECI_SKILLS, representing the percentage of board members with an industry-specific background (Ramón-Llorens et al., 2018). The third dependent variable used was the proportion of female board directors, labelled as WBOARD. This variable was measured as the ratio of the total number of women board directors to the total overall number of directors on boards (Terjesen and Singh, 2008; Grosvold and Brammer, 2011). The last dependent variable used was the existence of a corporate governance committee, referred to as CG_COMMT, and computed as a dummy variable that takes the value 1 if the firm has a committee, and 0 otherwise (Mallin and Michelon, 2011).

\subsection{Independent variables}

The independent variable was defined as either LME or CME, calculated as a dummy variable that takes the value 1 if the country is located in an LME, and 0 when the country is domiciled in a CME (Hall and Soskice, 2001; Hall and Soskice, 2006; Gallego-Álvarez and Quina-Custodio, 2017).

\subsection{Control variables}

A review of past empirical research allowed considering several control variables in this analysis. The board size (BODSIZE) - in line with Sauerwald et al. (2016) and De Andrés et al. (2017) — was calculated as the total number of directors on boards. The second control variable was company performance, proxied with Tobin's Q (García-Ramos et al., 2017) and denoted by Q_TOBIN. This variable was measured as the market capitalisation of common stock+book value liabilities divided by the book value of total assets. Furthermore, CEO power was also controlled. This variable is denoted by CEO_POW and is calculated as the aggregation of four dummy variables, in line with earlier research (Tien et al., 2014; Koo, 2015). These are: (1) CEO duality, which is a dummy variable that takes the value 1 if the same person serves simultaneously as CEO and chairman of the board, and 0 otherwise, (2) if the chairman of the board is an ex-CEO, which is a dummy variable that takes the value 1 if the chairman of the board held the CEO position in the company prior to becoming chairman and, 0 otherwise, (3) CEO tenure, which is a dummy variable that takes the value 1 if CEO tenure is above the sample median, and 0 otherwise, and (4) if the CEO is a board member, which is a dummy variable that takes the value 1 if the CEO serves as a board member, but not as chair of the board, and 0 otherwise. Company size (SIZE), was also controlled for, measured as the log of sales (Thomsen et al., 2016; García-Meca and Palacio, 2018). 
Leverage was defined as LEVERAGE, calculated as debt over total assets (Rees and Rodionova, 2015). The measure of industry sector was based on the paper by GallegoÁlvarez and Quina-Custodio (2017), which created nine dummy variables in the analysis representing the following activities: commodities, consumer cyclical, consumer non-cyclical, energy, healthcare, industrial, technology, telecommunications services, and utilities. These were based on the TRBC economic classification provided by Thomson Reuters. Finally, the effects of sector (SECTOR) and year (YEAR) were controlled for by considering a set of dummy variables in the model. Table 3 presents the summary of the dependent, independent, and control variables.

\section{$<$ Insert Table $3>$}

Thus, we have built four baseline models to verify the proposed hypotheses:

MODEL 1: CSR_DISC it $_{2}=\beta_{0}+\beta_{1}$ LME $_{\mathrm{it}}+\beta_{2}$ BODSIZE $_{\mathrm{it}}+\beta_{3}$ TOBIN_Q $\mathrm{Q}_{\mathrm{it}}+\beta_{4}$ CEO_POW ${ }_{i t}+\beta_{5}$ SIZE $_{i t}+\beta_{6}$ LEVERAGE $_{i t}+\sum \beta_{\mathrm{k}}$ SECTOR $_{\mathrm{i}}+\sum \beta_{\mathrm{j}} \mathrm{YEAR}_{\mathrm{t}}+\mho_{\mathrm{it}}+\varphi_{\mathrm{i}}$

MODEL 2: B_SPECI_SKILLS ${ }_{\mathrm{it}}=\beta_{0}+\beta_{1} \mathrm{LME}_{\mathrm{it}}+\beta_{2}$ BODSIZE $_{\mathrm{it}}+\beta_{3}$ TOBIN_Q $_{\mathrm{it}}+\beta_{4}$ CEO_POW ${ }_{\mathrm{it}}+\beta_{5} \mathrm{SIZE}_{\mathrm{it}}+\beta_{6} \mathrm{LEVERAGE}_{\mathrm{it}}+\sum \beta_{\mathrm{k}} \mathrm{SECTOR}_{\mathrm{i}}+\sum \beta_{\mathrm{j}} \mathrm{YEAR}_{\mathrm{t}}+\mho_{\mathrm{it}}+\varphi_{\mathrm{i}}$

MODEL 3: $\quad$ WBOARD $_{\mathrm{it}}=\beta_{0}+\beta_{1} \mathrm{LME}_{\mathrm{it}}+\beta_{2}$ BODSIZE $_{\mathrm{it}}+\beta_{3}$ TOBIN_Q $\mathrm{Q}_{\mathrm{it}}+\beta_{4}$ CEO_POW ${ }_{\mathrm{it}}+\beta_{5} \mathrm{SIZE}_{\mathrm{it}}+\beta_{6} \mathrm{LEVERAGE}_{\mathrm{it}}+\sum \beta_{\mathrm{k}} \mathrm{SECTOR}_{\mathrm{i}}+\sum \beta_{\mathrm{j}} \mathrm{YEAR}_{\mathrm{t}}+\mho_{\mathrm{it}}+\varphi_{\mathrm{i}}$ MODEL 4: $\quad$ CG_COMMT $_{i t}=\beta_{0}+\beta_{1}$ LME $_{\mathrm{it}}+\beta_{2}$ BODSIZE $_{\mathrm{it}}+\beta_{3}$ TOBIN_Q $\mathrm{Q}_{\mathrm{it}}+\beta_{4}$ CEO_POW ${ }_{i t}+\beta_{5}$ SIZE $_{i t}+\beta_{6}$ LEVERAGE $_{i t}+\sum \beta_{\mathrm{k}}$ SECTOR $_{\mathrm{i}}+\sum \beta_{\mathrm{j}} \mathrm{YEAR}_{\mathrm{t}}+\mho_{\mathrm{it}}+\varphi_{\mathrm{i}}$

where all the variables included have an " $i$ " subscript, which refers the company, and " $t$ " represents the year. Moreover, $\beta_{0}$ is the intercept and $\beta 1 \ldots \beta \mathrm{n}$ are the regression coefficients. The random error term $\left(\mho_{i t}+\varphi_{i}\right)$ can be separated into two components: the disturbance term, $\mho_{i t}$, varying the cross-section and cross-time combined effect, and the individual or company-specific effect, $\varphi_{\mathrm{i}}$ (the unobservable heterogeneity), which is invariant over time and varies among individuals (Greene, 1998).

The dynamic panel data estimator of the generalised method of moments (GMM) proposed by Arellano and Bond (1991) and Blundell and Bond (1998) was used. Different to other estimators, the GMM procedure is consistent and efficient because it deals with unobservable heterogeneity $\left(\varphi_{\mathrm{i}}\right)$ by modelling it as an individual effect, and by eliminating it with the first differences in variables. The dynamics of the procedure are controlled with the dynamic panel data method by lagging the dependent variable (introducing temporal 
dependency). Additionally, the GMM procedure also takes into account the endogeneity, and reduces the estimation bias.

The GMM procedure offers the Arellano-Bond tests $\mathrm{AR}(1)$ and $\mathrm{AR}(2)$, and the Hansen test. The Arellano-Bond test $\operatorname{AR}(2)$ enables the analysis to show whether there is a second-order serial correlation in the first difference residuals. The second-order serial correlation will not be a concern if the null hypothesis of non-serial correlation is rejected ( $p>0.1$ ). Additionally, the Hansen test of over-identifying restrictions will confirm whether the instruments used in the estimation are suitable by rejecting $(p>0.1)$ the null hypothesis of non-correlation between the instruments and the error term.

\section{Results}

\subsection{Descriptive analysis}

Table 4 reports the main descriptive statistics for all variables. Concerning the dependent variables, the companies in our sample disclosed, on average, 28.08 items out of 112; the percentage of board members with an industry-specific background (board specific skills) was, on average, $57.89 \%$, the proportion of female directors on boards (WBOARD) was, on average, $12.50 \%$, whilst $53.43 \%$ of the companies have a corporate governance committee (CG_COMMT). Additionally, $70.17 \%$ of the companies in the sample operated in an LME. With respect to company characteristics, the average board size was 10.44 members, company performance measured with Tobin's Q was 0.72 , CEO power was, on average, 1.64, company size was 9.61 (log of sales) and leverage was, on average, 11.05\%. Finally, 13.75\% of the companies in the sample belong to the commodities sector, $19.92 \%$ to consumer cyclicals, $9.98 \%$ to consumer non-cyclical, $8.66 \%$ to energy, $8.92 \%$ to healthcare, $21.65 \%$ to industrials, $8.73 \%$ to technology, $3.30 \%$ to telecommunication services, and $5.10 \%$ to utilities.

\section{$<$ Insert Table 4>}

A correlation matrix has been built to check for multicollinearity. The correlation coefficients reported in Table 5 were lower than 0.8 (see Archambeault and DeZoort, 2001), whereby we may conclude that multicollinearity is not a concern in our research. Moreover, the variance inflation factors (VIFs) have also been calculated. None (as shown in Table 5) is higher than 10. VIFs that exceed values of 10 reveal multicollinearity problems (Greene, 1998; O’Brien, 2007). Thus, multicollinearity is not a concern in our research.

\footnotetext{
$<$ Insert Table 5>
} 


\subsection{Multivariate analysis}

Table 6 presents the results of the regressions run to test the hypotheses posited. Four different models were run. In Model 1, we explored whether CSR disclosure would be lower in LMEs than in CMEs. The variable LME had a positive sign, contrary to our predictions, but was not statistically significant, which led us to reject the first hypothesis. This finding shows that companies operating in LMEs are equally likely to disclose CSR information as those operating in CMEs, although most previous research suggests that CSR disclosure is higher in CME countries (e.g., Aguilera and Jackson, 2010; Brammer et al., 2012; Favotto et al., 2016). This evidence supports the view that CSR reporting is not influenced by varieties of capitalism, which is also contrary to what some scholars (i.e., Kinderman, 2012) argue, namely, that there is a higher development of CSR practices and institutions in LMEs because they may substitute the lack of extensive public regulation, and might provide companies with a source of legitimacy "in countries where the state only minimally compensates those not well served by the market" (Favotto et al., 2016, p. 14). Thus, our findings show that past evidence on the higher level of CSR disclosure in CMEs countries is not conclusive, and there is therefore a need to shed new light on this topic by considering not only CSR reporting as a whole, but also by separately analysing the different dimensions of CSR, such as human rights and environmental and social issues, to explore how they are affected by varieties of capitalism.

\section{$<$ Insert Table 6>}

Model 2 examined whether board-specific skills - measured as the percentage of board members who have an industry-specific background-were lower in LMEs than in CMEs. The result for LMEs was negative and significantly related to the dependent variable board-specific skills. Thus, the percentage of board members with an industry-specific background is lower in LMEs than in CMEs, and hypothesis 2 cannot therefore be rejected. This result is consistent with Hall and Gingerich (2009), Schneider (2009), and Kiran (2018), who support the view that labour relations in CMEs are characterised by coordinated wagebargaining, high levels of employment protection, and strong unions, which allow companies to confer high levels of industry-specific skills to their workers and directors. While companies domiciled in LMEs are focused on satisfying the needs of shareholders, companies in CMEs are more interested in safeguarding the interests of stakeholders. This could also explain why companies operating in CMEs tend to have boards with more specific skills (such as an industry-specific background) because with these specific skills they will be more likely to satisfy stakeholders' needs and demands. 
Model 3 explored whether the proportion of female directors on boards was higher in LMEs than in CMEs. This variable had a positive sign, as expected, and is statistically significant, supporting the third hypothesis. Thus, we cannot reject the third hypothesis. This finding indicates that companies operating in LMEs have more women directors on boards than those operating in CMEs, consistent with Mandel and Semyonov (2006) and Grosvold and Brammer (2011). The significant increase in the success and advancement of female directors in positions of responsibility in LMEs (in comparison to other economies) may explain this result. Furthermore, Mandel and Shalev (2009) take into account varieties of capitalism in order to analyse the best position of female directors in LMEs, and suggest that LMEs implement a neutral position in the determination of roles in the labour market and the division of responsibilities in relation to the work-family dichotomy.

In Model 4, the aim was to explore whether the presence of corporate governance committees is higher in LMEs than in CMEs. The coefficient was positive, as predicted, and significant, so the fourth hypothesis cannot be rejected. This evidence confirms that companies operating in LMEs are more likely to create a corporate governance committee than companies domiciled in CMEs. Thus, these results are consistent with the findings of Chizema and Shinozawa (2012), who report that the presence of corporate committees is more usual in LMEs, where the corporate governance style is oriented toward the shareholder value model (Aguilera and Jackson, 2003; Yoshikawa et al., 2007). This result can be explained because the presence of corporate governance committees improves the behaviour of boards, strengthening the protection of shareholders' interests, which is a relevant attribute of LMEs.

Regarding control variables, CEO power was only positive and statistically significant for Model 2, where the percentage of board members with an industry-specific background is the dependent variable. The leverage variable was significant and negatively correlated with CSR disclosure, not affecting all the other dependent variables. Finally, companies operating in commodities, consumer cyclical, energy, and industrial and utility sectors were negative and significantly correlated with the presence of female directors on boards. None of the other control variables was statistically significant.

\subsection{Robustness analysis}

In Table 7, we perform a robustness analysis by estimating the models with panel data firm fixed-effects. With this estimator, we control unobserved firm fixed-effects, namely, unobserved time-constant firm heterogeneity (Desender and Epure, 2015). Furthermore, we 
have also controlled for time fixed-effects by taking into account year dummy variables to address the potential endogeneity associated with the variations in our dependent variables in all companies. Table 7 shows that the first hypothesis is rejected, and the second, third and fourth ones are accepted, in line with the findings provided by the GMM procedure. We reach the same conclusions estimating the models with GMM and with firm fixed-effects estimators.

\section{Discussion and conclusions}

This research contributes to prior literature on the influence of different institutional contexts with regard to specific corporate governance attributes: CSR disclosure, boardspecific skills, female directors on corporate boards, and corporate governance committees. We have taken as our reference the varieties of capitalism perspective, which has scarcely been used in previous research (Jackson and Apostolakou, 2010), to explain the variations and changes that exist within capitalist systems through a broad dichotomy of institutional contexts in LMEs and CMEs (Hall and Soskice, 2001; Hancke et al., 2007; Vitols 2001; Hall and Gingerich, 2009). The main emphasis of the research in this field has focused on the distinctive nature of the institutional contexts in which companies operate, based on indexes such as the legal system and government, sources of financing and skills, educational systems, the influence of other social networks, and factors such as unions and regulatory authorities.

The paper's initial focus was that the institutional contexts for LMEs and CMEs can affect different aspects of corporate governance in different ways within the framework of varieties of capitalism, because as Aguilera and Jackson (2010) suggest, organisations operating under the same institutional context are pressured to behave similarly. This leads to companies belonging to specific contexts being homogeneous and adopting the same model of corporate governance.

Next, we consider the four hypotheses proposed in the study. The first states that CSR reporting is lower in LME countries than in CME countries. This is rejected because the findings show - contrary to our predictions - that companies located in LME countries have the same probability of reporting CSR issues as companies operating in CME countries. The second hypothesis argues that board-specific skills are higher in CME countries than in LME countries, which is accepted. Our results therefore suggest that in CME contexts, the labour market is less flexible than in LME countries, unions are stronger, and employment protection is higher, which result in training programmes that are more relevant to workers. Board directors will provide these specific skills, and allow companies to satisfy stakeholders' 
interests better because CME countries are more oriented towards stakeholders than shareholders. The third hypothesis, which posits that the proportion of female directors on boards is higher in LMEs than in CMEs, is accepted. This may be because the progress of women in management positions and board directorships has been greater in LMEs such as the US (Mandel and Semyonov, 2006). In this type of countries, women are freer to compete with men for the highest positions, and this makes women achieve more relevant positions within boards in the institutional environment of LMEs. The non-rejection of the fourth hypothesis allows us to conclude that the existence of corporate governance committees is higher in LMEs than in CMEs. This result can be explained (as supported by Chizema and Shinozawa, 2012) because the existence of committees is a common practice in Englishspeaking countries, within their style of corporate governance oriented toward the shareholder value model (Aguilera and Jackson, 2003; Yoshikawa et al., 2007).

Thus, the results support the paper's initial thesis that companies belonging to a specific context are homogeneous and adopt the same model of corporate governance. This evidence may be because different aspects of corporate governance were analysed within the framework of varieties of capitalism.

This research also has practical implications. Firstly, with regard to managerial implications, our findings suggest that belonging to a specific variety of capitalism affects various mechanisms of corporate governance. Hence, these findings may have implications for managers when deciding which country to invest in, depending on the firms' corporate governance structure. In this regard, if they do so in an LME country, the structure of corporate governance is determined by a high proportion of women directors on boards, and boards characterised by having corporate governance committees, which are mechanisms of vital importance for ensuring the board fulfils its duties. However, boards in these countries will have directors with general skills in comparison to CME countries, where board members are characterised by having specific skills, such as an industry-specific background. Concerning CSR disclosure, it does not matter whether firms operate in LME or CME contexts because there is no difference between them in relation to the reporting of CSR information. Managers in both types of countries will be able to find firms disclosing similar CSR matters. Secondly, our findings concerning the incorporation of female directors on corporate boards may be useful for policymakers, regulators, and corporate decision-makers. Our results suggest that the proportion of women directors is higher in LMEs than CMEs. In countries such as Norway and Spain, for instance (more oriented to a CME), initiatives have been implemented to increase the presence of female directors on boards. However, according 
to our evidence, it would appear that these initiatives have not been as effective as expected. Thus, policymakers in countries domiciled in CME countries should complement these initiatives with other policies or measures that are more effective at increasing the presence of women directors on boards, given the benefits of the female leadership style in the decisionmaking process (Pucheta-Martínez et al., 2018).

As a final observation, this paper has a number of limitations. Firstly, it is possible that all the factors affecting our dependent variables, according to theory and empirical evidence, have not been controlled. Secondly, some control variables used in this research (such as CEO power) have been measured by focusing on past research, but it is also possible to measure this variable in another way. Finally, our study is based on a particular period, and so our evidence should not be extended to other periods.

Our study offers several potential research opportunities. On the one hand, it would be interesting to explore other board attributes, such as the role of executive and institutional directors in LMEs. This new evidence would extend our conclusions. Conversely, future research might explore in more detail how board characteristics in countries operating in CMEs might improve the effectiveness of corporate governance.

\section{COMPLIANCE WITH ETHICAL STANDARDS}

The authors declare that they have no conflict of interest.

This article does not contain any studies with participants involving any of the authors.

\section{References}

Aguilera, R. V., Jackson, G., 2003. The Cross-National Diversity of Corporate Governance: Dimensions and Determinants. Acad. Manage. Rev. 28, 447-465.

Aguilera, R., Rupp, D., Williams, C., Ganapathi, J., 2007. Putting the S Back in CSR: A Multi-level theory of social change in organizations. Acad. Manage. Rev. 32(3), 836863.

Aguilera, R., Jackson, G., 2010. Comparative and International Corporate Governance. The Acad. Manag. Ann. 4, (1), 485-556.

Amable, B., 2003. The Diversity of Modern Capitalism, Oxford: Oxford University Press.

Amaeshi, K., Amao, O., 2009. Corporate Social Responsibility in Transnational Spaces: Exploring Influences of Varieties of Capitalism on Expressions of Corporate Codes of Conduct in Nigeria. J. Bus. Eth. 86, 225-239.

Andrews, K., 1997. The Concept of Corporate Strategy, in Foss, N. J. (Ed. A Resources Firms and Strategies: A reader in the resource-based perspective. Oxford University Press, UK.

Archambeault, D., DeZoort, F. T. 2001. Auditor opinion shopping and the audit committee: An analysis of suspicious auditor switches. Inter. Journ. of Audit. 5, 33-52.

Arellano, M., 2003. Panel Data Econometrics. Oxford: Oxford University Press. 
Arellano, M., Bond, S., 1991. Some Tests of Specification for Panel Data: Monte Carlo Evidence and an Application to Employment Equations. The Rev. of Econ. Stud. 58(2), 277-297.

Bhagat, S., Bolton, B., 2008. Corporate governance and firm performance. J. Corp. Finan. 14, 257-273.

Bianco, M., Casavola, P., 1999. Italian Corporate Governance: Effects on Financial Structure and Firm Performance. Europ. Econ. Rev. 43(4), 1057-1069.

Blundell, R., Bond, S.,1998. Initial conditions and moment restrictions in dynamic panel data models. J. Econom. 87(1), 115-143.

Bosch, G., Charest, J., 2008. Vocational Training and the Labour Market in Liberal and Coordinated Economies, Blackwell Publishing.

Brammer, S., Jackson, G., Matten, D., 2012. Corporate social responsibility and institutional theory: New perspectives on private governance. Soc-Econ Rev. 10, 3-28.

Cadbury report., 1992. Committee of the financial aspects of corporate governance. In The Financial Aspects of Corporate Governance. London: London Stock Exchange.

Campbell, J. L., 2007. Why would corporations behave in socially responsible ways? An institutional theory of corporate social responsibility. Acad. Manag. Rev. 32, 946-967.

Carney, R. W., Witt, M. A., 2012. The role of the state in Asian business systems. http://papers.ssrn.com/sol3/papers.cfm?abstract_id=2188887.

Chen, X., Cheng, Q., Wang, X., 2015. Does increased board independence reduce earnings management? Evidence from recent regulatory reforms. Rev. of Accoun. Stud. 20 (2), 899-933.

Chizema, A., Shinozawa, Y., 2012. The company with committees: change or continuity in Japanese corporate governance? J. Manag. Stud. 49 (1), 77-101.

De Andrés, P., Arranz-Aperte, L., Rodríguez-Sanz, J.A., 2017. Independent versus nonindependent outside directors in European companies: Who has a say on CEO compensation? Bus. Resear. Quart. 20(2), 79-95.

Desender, K., Epure, M. 2015. Corporate governance and corporate social performance: The influence of boards, ownership and institutions. Barcelona GSE Working paper series, Working paper $\mathrm{n}^{\mathrm{o}}$ 730, Graduate School of Economics, Barcelona GSE, Spain. https://papers.ssrn.com/sol3/papers.cfm?abstract_id=2570963.

Dore, R., 2000. Stock Market Capitalism: Welfare Capitalism, Japan and Germany Versus the Anglo-Saxons, (Oxford University Press, Oxford).

Estévez-Abe, M., 2005. Gender bias in skills and social policies: the varieties of capitalism perspective on sex segregation. Soc. Pol: Intern. Stud. in Gen. Sta. and Soc. 12(2), $180-215$.

Estévez-Abe, M., 2006. Gendering the varieties of capitalism. A study of occupational segregation by sex in advanced industrial societies. Worl. Polit. 59(1), 142-175.

Fainshmidt, S., Judge, W. Q., Aguilera, R. V., Smith, A., 2018. Varieties of institutional systems: A contextual taxonomy of understudied countries. J. of Wor. Bus. 53 (3), 307-322

Fama, E.F., 1980. Agency problems and the theory of the firm. J. Polit. Econ. 88(2), 288-307.

Favotto, A., Kollman, K., Bernhagen, P. 2016. Engaging firms: The global organisational field for corporate social responsibility and national varieties of capitalism. Poli. and Soc. 35, 13-27.

Finegold, D., Soskice, D., 1988. The Failure of Training in Britain: Analysis and Prescription. Oxf. Rev. Econ. Pol. 4, 21-53.

Freeman, R., Harrison, J., Wicks, A., 2007. Managing for stakeholders: Survival, reputation, and success. New Haven, CT: Yale University Press. 
Gallego-Álvarez, I., Quina-Custodio, I. A., 2017. Corporate social responsibility Reporting and varieties of capitalism: an international analysis of state-led and liberal market economies. Corporate Social Responsibility and Environmental Management. 24 (6), 478-495.

Gallego-Álvarez, I., Ortas, E., 2017. Corporate environmental sustainability reporting in the context of national cultures: A quantile regression approach. Int. Bus. Rev. 2, 337-353.

García-Meca, E., Palacio, C.J., 2018. Board composition and firm reputation: The role of business experts, support specialists and community influentials. BRQ Bus. Resear. Quart. 21(2), 111-123.

García-Ramos, R., Díaz-Díaz, B., García-Olalla, M., 2017. Independent directors, large shareholders and firm performance: the generational stage of family businesses and the socioemotional wealth approach. Rev. Manag. Sci. 11,119-156.

Greene, W. H. 1998. Econometric analysis, third edition. New Jersey: Prentice Hall.

Grosvold, J., Brammer, S. 2011. National institutional systems as antecedents of female board representation: an empirical study. Corp. Gover: An Intern. Rev. 19 (2), $113-$ 135.30116

Hall, P., 2007. The evolution of varieties of capitalism in Europe, in B. Hancke, M. Rhodes and M. Thatcher (ed), Beyond Varieties of Capitalism: Conflict, Contradictions and Complementarities in the European Economy, Oxford: Oxford University Press.

Hall, P., Gingerich, D., 2009. Varieties of Capitalism and Institutional Complementarities in the Political Economy: An Empirical Analysis. Brit. J. of Polit. Scien. 39, 449-482.

Hall, P. A., Soskice, D. A., 2001. Varieties of capitalism: The institutional foundations of comparative advantage. Oxford: Oxford University Press.

Hall, P.A., Soskice, D. W., 2003. Varieties of Capitalism: The Institutional Foundations of Comparative Advantage, Oxford University Press

Hall, P., Soskice, D., 2006. Variedades de Capitalismo: algunos aspectos fundamentales. Des. Econ. 45 (180), 17.

Hancke, B., Rhodes, M., Thatcher, M., 2007. Introduction: beyond varieties of capitalism. IN: B. Hancke, M. Rhodes and M. Thatcher (Eds.), Beyond Varieties of Capitalism: conflict, contradictions, and complementarities in the European economy. Oxford: Oxford University Press.

Harrison, J. R., 1987. The strategic use of Corporate Board Committees. Calif. Manag. Rev. 30 (1), 109-125.

Hartmann, J., Uhlenbruck, K., 2015. National institutional antecedents to corporate environmental performance. J. of Wor. Bus. 50 (4), 729-741.

Hillman, A., Cannella, J., Paetzold, R., 2000. The resource dependence role of corporate directors: strategic adaptation of board composition in response to environmental change. J. Manag. 37, 235-256.

Hossain, M., Prevost, A. K., Rao, R. P., 2001. Corporate Governance in New Zealand: The Effect of the 1993 Companies Act on the Relation Between Board Composition and Firm Performance. Pac-Bas. Finan. J. 9(2), 119-145.

Huang, H., Lobo, G. J., Zhou, J., 2009. Determinants and accounting consequences of forming a governance committee: evidence from the United. Corp. Govern: An Intern. Rev. 17 (6), 710-727.

Ioannou, I., Serafeim, G., 2012. What drives corporate social performance? The role of nation-level institutions. J. of Inter. Busi. Stud. 45 (9), 834-864.

Jackson, G., Apostolakou, A., 2010. Corporate social responsibility in Western Europe: An institutional mirror or substitute? J. of Bus. Eth. 94, 371-394.

Jamali, D., 2006. Insights into triple bottom line integration from a learning organization perspective. Bus. Proc. Manag. J. 12, 809-821. 
Jamali, D., Safieddine, A., Rabbath, M., 2008. Corporate governance and corporate social responsibility synergies and interrelationships. Corp. Govern: An Intern. Rev. 16(5), 443-459.

Jensen, M., 2002. Value maximization, stakeholder theory, and the corporate objective function. Bus. Eth. Quart. 12, 235-256.

Jensen, M.C., 1993. The modern industrial revolution, exit, and the failure of internal control systems. J. Finan. 48, 831-880.

Jensen, M. C., and Meckling, W. H., 1976. Theory of the firm: Managerial behavior, agency costs and ownership structure. J. of Finan. Econ. 3(4), 305-360.

Johanson, D., Østergren, K., 2010. The movement toward independent directors on boards: A comparative analysis of Sweden and the UK. Corp. Govern: An Intern. Rev. 18 (6), $527-539$.

Johnson, J. L., Daily, C. M., Ellstrand, A.E., 1996. Boards of directors: A review and research agenda. J. of Manag. 22 (3), 409-438.

Johnson, S. G., Schnatterly, K., Hill, A. D., 2013. Board Composition Beyond Independence: Social Capital, Human Capital, and Demographics. J. Manag. 39 (1), 232-262.

Kang, N., Moon, J., 2012. Institutional complementarity between corporate governance and Corporate Social Responsibility: a comparative institutional analysis of three capitalisms. Soc-Econ. Rev. 10, 85-108.

Kiel, G.C., Nicholson, G. J. (2003). Board Composition and Corporate Performance: how the Australian experience informs contrasting theories of corporate governance Corp. Govern: An Intern. Rev. 11(3), 189-205.

Kinderman, D., 2012. Free us up so we can be responsible!' The co-evolution of corporate social responsibility and neo-liberalism in the UK, 1977-2010. Soc-Econ. Rev. 10 (1), 29-57.

Kiran, J., 2018. Expanding the framework of the varieties of capitalism: Turkey as a hierarchical market economy. Jour. of Euras. Stud. 9, 42-51.

Koo, K., 2015. The effects of CEO power on firm value: Evidence from the financial crisis of 2008. Account. and Finan. Resear. 4(4), 13-25.

La Porta, R., Lopez-de-Silanes, F., Shleifer, A., Vishny, R.,1998. Law and finance. J. Polit. Econ. 106, 1113-1155.

Mallin, C. A., Michelon, G., 2011. Board reputation attributes and corporate social performance: An empirical investigation of the US best corporate citizens. Acc. Busin. Resear. 41(2), 119-144.

Mandel, H., Semyonov, M., 2006. A Welfare State Paradox: State Intervention and Women's Employment Opportunities in 22 Countries. Am. J. of Soc. 111 (6), 1910-49.

Mandel, H., Shalev, M., 2009. Gender, class and varieties of capitalism. Soc. Polit: Intern. Stud. in Gen. Stat. and Soci. 16(2), 161-181.

Matten, D., Moon, J., 2008. "Implicit" and "explicit" CSR: a conceptual framework for a comparative understanding of corporate social responsibility. Acad. of. Manag. Revi. 33 (2), 404-424.

O'Brien, R. M., 2007. A caution regarding rules of thumb for variance inflation factors. Qual. and Quant., 41, 673-690.

Pfeffer, J., Salancik, G. R., 1978. The External Control of Organizations: A Resource Dependence Perspective. Harper and Row, New York.

Pucheta-Martínez, M. C., Bel-Oms, I., Olcina-Sempere, G., 2016. Corporate governance, female directors and quality of financial information. Bus. Eth: A Eur. Rev. 25(4), 363-385.

Pucheta-Martínez, M. C., Bel-Oms, I., Olcina-Sempere, G., 2018. The association between board gender diversity and financial reporting quality, corporate performance and 
corporate social responsibility disclosure: A literature review. Acad. Rev. Latinoam. Administ. 31(1), 177-194.

Ramón-Llorens, C., García-Meca, E., Pucheta-Martínez, M. C. 2018. The role of human and social board capital in driving CSR reporting. Lon. Ran. Plan., https://doi.org/10.1016/j.lrp.2018.08.001

Rees, W., Rodionova, T., 2015. The influence of family ownership on corporate social responsibility: An international analysis of publicly listed companies. Corp. Govern: An Internat. Rev. 23(3), 184-202.

Rogelberg, S. G., Rumery, S. M., 1996. Gender diversity, team decision quality, time on task, and interpersonal cohesion. Sm. Gro. Resear. 27(1), 79-90.

Rupp, D. E., Mallory, D. B., 2015. Corporate social responsibility: psychological, personcentric, and progressing. Ann. Rev. Organ. Psych. and Organ. Beh., 2, 211-236.

Sauerwald, S., Van Oosterhout, J. H., Van Essen, M., 2016. Expressive shareholder democracy: A multilevel study of shareholder dissent in 15 Western European countries. J. Manag. Stud. 53(4), 520-551.

Schneider, B. R., 2009. Hierarchical market economies and varieties of capitalism in Latin America. J. Lat. Amer. Stud. 41, 553-575.

Shleifer, A., Vishny, R.,1997. A survey of corporate governance. J. Finan. 12(2), 737- 783.

Soskice, D., 2007. Macroeconomics and varieties of capitalism, in B. Hancke, M. Rhodes and M. Thatcher (eds), Beyond Varieties of Capitalism: Conflict, Contradictions and Complementarities in the European Economy, Oxford: Oxford University Press.

Tao, N., Hutchinson, M., 2013. Corporate governance and risk management: The role of risk management and compensation committees. J. Contem. Acco. Econ. 9(1), 83-99.

Terjesen, S., Singh, V., 2008. Female presence on corporate boards: A multi-country study of environmental context. J. Busin. Eth. 83, 55-63.

Thomsen, S., Rose, C., Kronborg, D., 2016. Employee representation and board size in the Nordic countries. Europ. J. of Law Econ. 42(3), 471-490.

Tien, Ch., Chen, Ch.-N., Chuang, Ch-M., 2014. A study of CEO power, pay structure, and firm performance. Journ. Mang. Organiz. 19(4), 424-453.

Vafeas, N., Theodorou, E., 1998. The relationship between board structure and firm performance in the UK. Brit. Acc. Rev. 30, 383-407.

Vitols, S., 2001. Varieties of corporate governance: Comparing Germany and the UK. In P. Hall \& D. Soskice (Eds.), The varieties of capitalism: The institutional foundations of comparative advantage: 337-360. Oxford: Oxford University Press.

Useem, M., 1996. Investor capitalism. New York: Basic Books.

Whitley, R., 1999. Divergent capitalisms: The social structuring and change of business systems. Oxford: Oxford University Press.

Whitley, R., 2005. How national are business systems? The role of states and complementary institutions in standardizing systems of economic coordination and control at the national level. In G. Morgan, R. Whitley, \& E. Moen (Eds), Changing capitalisms? Internationalization, institutional change, and systems of economic organization: 190234. Oxford: Oxford University Press.

Wincent, J., Anokhin, S., Örtqvist, D., 2010. Does network board capital matter? A study of innovative performance in strategic SME networks. J. Bus. Res. 63 (3), 265-275

Yoshikawa, T., Tsui-Auch, L. S., McGuire, J., 2007. Corporate governance reform as institutional innovation: The case of Japan. Organ. Scien. 18, 973-88.

Zheka, V., 2005. Corporate governance, ownership structure and corporate efficiency: The case of Ukraine. Man. Decis. Econ. 26 (7), 451-460. 
Table 1

Number of observations by country

\begin{tabular}{lccc}
\hline Country & Observations & Percentage & Cum. \\
\hline Australia & 793 & 7.9 & 7.9 \\
Austria & 34 & 0.3 & 8.2 \\
Belgium & 90 & 0.9 & 9.1 \\
Canada & 1125 & 11.2 & 20.3 \\
Denmark & 110 & 1.1 & 21.4 \\
Finland & 137 & 1.4 & 22.8 \\
Germany & 357 & 3.6 & 26.3 \\
Ireland & 174 & 1.7 & 28.1 \\
Japan & 1515 & 15.1 & 43.2 \\
Netherlands & 218 & 2.2 & 45.3 \\
New Zealand & 52 & 0.5 & 45.9 \\
Norway & 61 & 0.6 & 46.5 \\
Sweden & 218 & 2.2 & 48.6 \\
Switzerland & 380 & 3.8 & 52.4 \\
United Kingdom & 1198 & 11.9 & 64.3 \\
United States & 3581 & 35.7 & 100.0 \\
\hline Total & $\mathbf{1 0 , 0 4 3}$ & $\mathbf{1 0 0}$ & \\
\hline
\end{tabular}

Table 2

Number of observations by activity sector

\begin{tabular}{lccc}
\hline \multicolumn{1}{c}{ TRBC economic sector name } & Number of observations & Percentage & Cum. \\
\hline Basic Materials & 1381 & 13.8 & 13.8 \\
Consumer cyclical, & 2001 & 19.9 & 33.7 \\
Consumer Non-Cyclical & 1002 & 10.0 & 43.7 \\
Energy & 870 & 8.7 & 52.3 \\
Healthcare & 896 & 8.9 & 61.2 \\
Industrial & 2174 & 21.6 & 82.9 \\
Technology & 877 & 8.7 & 91.6 \\
Telecommunications Services & 331 & 3.3 & 94.9 \\
Utilities & 511 & 5.1 & 100.0 \\
\hline Total & 10,043 & 100.0 & \\
\hline
\end{tabular}


Table 3

Variables description

\begin{tabular}{|c|c|}
\hline Variables & Description \\
\hline CSR_DISC & The aggregation of 112 items concerning social and environmental issues \\
\hline B_SPECI_SKILLS & The percentage of board members who have an industry-specific background \\
\hline WBOARD & $\begin{array}{l}\text { The proportion of female directors on boards= Total number of female directors on } \\
\text { boards/Total number of directors on boards }\end{array}$ \\
\hline CG_COMMT & $\begin{array}{l}\text { Dummy variable that takes the value } 1 \text { if the firm has a Corporate Governance } \\
\text { Committee and } 0 \text {, otherwise }\end{array}$ \\
\hline LME & $\begin{array}{l}\text { Dummy variable that takes the value } 1 \text { if the country operates in a liberal market } \\
\text { economy and } 0 \text {, if the country operates in a coordinated market economy }\end{array}$ \\
\hline BODSIZE & The total number of directors on boards \\
\hline Q_TOBIN & $\begin{array}{l}\text { The market capitalization of common stock+ book value liabilities divided by the book } \\
\text { value of total assets }\end{array}$ \\
\hline CEO_POW & $\begin{array}{l}\text { The aggregation of four dummies variables: (1) Ceo duality, which is a dummy variable } \\
\text { that takes the value } 1 \text { if the same person serves simultaneously as CEO and chairman of } \\
\text { the board and } 0 \text {, otherwise, (2) the Chairman of the board is ex-CEO, which is a dummy } \\
\text { variable that takes the value } 1 \text { if the chairman of the board held the CEO position in the } \\
\text { company prior to becoming chairman and } 0 \text {, otherwise, ( } 3 \text { ) CEO tenure, which is a } \\
\text { dummy variable that takes the value } 1 \text { if CEO tenure is above the sample median and } 0 \text {, } \\
\text { otherwise and (4) CEO board member, which is a dummy variable that takes the value } 1 \\
\text { if the CEO serves as a board member, but not as chair of the board and } 0 \text {, otherwise }\end{array}$ \\
\hline SIZE & The log of total sales \\
\hline LEVERAGE & Debt over total assets \\
\hline BASIC MATERIALS & Dummy variable: $1=$ Basic Materials; $0=$ Otherwise \\
\hline CONSUMER CYCLICAL & Dummy variable: $1=$ Consumer Cyclical; $0=$ Otherwise \\
\hline $\begin{array}{l}\text { CONSUMER NON- } \\
\text { CYCLICAL }\end{array}$ & Dummy variable: $1=$ Consumer Non-Cyclical; $0=$ Otherwise \\
\hline ENERGY & Dummy variable: $1=$ Energy; $0=$ Otherwise \\
\hline HEALTHCARE & Dummy variable: $1=$ Healthcare; $0=$ Otherwise \\
\hline INDUSTRIALS & Dummy variable: $1=$ Industrial; $0=$ Otherwise \\
\hline TECHNOLOGY & Dummy variable: $1=$ Technology; $0=$ Otherwise \\
\hline $\begin{array}{l}\text { TELECOMMUNICATION } \\
\text { SERVICES }\end{array}$ & Dummy variable: $1=$ Telecommunication Services; $0=$ Otherwise \\
\hline UTILITIES & Dummy variable: $1=$ Utilities; $0=$ Otherwise \\
\hline
\end{tabular}


Table 4

Descriptive analysis

\begin{tabular}{lcccccc}
\hline \multicolumn{1}{c}{ Variable } & Obs & Mean & $\begin{array}{c}\text { Std. } \\
\text { Dev. }\end{array}$ & p25 & p50 & p75 \\
\hline CSR_DISC & 10,043 & 28.082 & 17.801 & 12.000 & 27.000 & 42.000 \\
B_SPECI_SKILLS & 10,043 & 57.897 & 23.875 & 41.667 & 57.143 & 75.000 \\
WBOARD & 10,043 & 12.498 & 10.981 & 0.000 & 11.111 & 20.000 \\
CG_COMMT & 10,043 & 53.430 & 49.884 & 0.000 & 1.000 & 1.000 \\
LME & 10,043 & 70.168 & 45.754 & 0.000 & 1.000 & 1.000 \\
BODSIZE & 10,043 & 10.439 & 3.249 & 8.000 & 10.000 & 12.000 \\
Q_TOBIN & 10,043 & 0.712 & 0.255 & 0.551 & 0.682 & 0.836 \\
CEO_POW & 10,043 & 1.643 & 0.740 & 1.000 & 2.000 & 2.000 \\
SIZE & 10,043 & 9.610 & 1.433 & 9.350 & 9.756 & 10.206 \\
LEVERAGE & 10,043 & 11.05 & 61.25 & 2.570 & 5.520 & 1.040 \\
BASIC MATERIALS & 10,043 & 13.751 & 34.440 & 0.000 & 0.000 & 0.000 \\
CONSUMER CYCLICAL & 10,043 & 19.924 & 39.945 & 0.000 & 0.000 & 0.000 \\
CONSUMER NON-CYCLICAL & 10,043 & 9.977 & 29.970 & 0.000 & 0.000 & 0.000 \\
ENERGY & 10,043 & 8.663 & 28.130 & 0.000 & 0.000 & 0.000 \\
HEALTHCARE & 10,043 & 8.922 & 28.507 & 0.000 & 0.000 & 0.000 \\
INDUSTRIALS & 10,043 & 21.647 & 41.186 & 0.000 & 0.000 & 0.000 \\
TECHNOLOGY & 10,043 & 8.732 & 28.232 & 0.000 & 0.000 & 0.000 \\
TELECOMMUNICATION SERVICES & 10,043 & 3.296 & 17.854 & 0.000 & 0.000 & 0.000 \\
UTILITIES & 10,043 & 5.089 & 21.977 & 0.000 & 0.000 & 0.000 \\
\hline
\end{tabular}

Mean, standard deviation and percentiles. CSR DISC is calculated as the aggregation of 112 items concerning social and environmental issues; B_SPECI_SKILLS is mesuread as the percentage of board members who have an industry-specific background; WBOARD is calculated as the proportion of female directors on boards; CG_COMMT is calculated as dummy variable that takes the value 1 if the firm has a Corporate Governance Committee and 0, otherwise; LME is measured as a dummy variable that takes the value 1 if the country operates in a liberal market economy and 0 , if the country operates in a coordinated market economy; BODSIZE is the total number of directors on boards; Q TOBIN is calculated as the market capitalization of common stock+ book value liabilities divided by the book value of total assets; CEO_POW is measured as the aggregation of four dummies variables: (1) Ceo duality,which is a dummy variable that takes the value 1 if the same person serves simultaneously as CEO and chairman of the board and 0 , otherwise, (2) the Chairman of the board is ex-CEO, which is a dummy variable that takes the value 1 if the chairman of the board held the CEO position in the company prior to becoming chairman and 0, otherwise, (3) CEO tenure, which is a dummy variable that takes the value 1 if CEO tenure is above the sample median and 0 , otherwise and (4) CEO board member, which is a dummy variable that takes the value 1 if the CEO serves as a board member, but not as chair of the board and 0, otherwise; SIZE is the log of total sales; LEVERAGE is the debt over total assets; BASIC MATERIALS if the company operates in Basic Materials sector and 0, otherwise; CONSUMER CYCLICALS if the company operates in Consumer Cyclicals sector and 0, otherwise; CONSUMER NON-CYCLICALS if the company operates in Consumer Non-Cyclicals sector and 0 , otherwise; ENERGY if the company operates in Energy sector and 0, otherwise; HEALTHCARE if the company operates in Healthcare sector and 0, otherwise; INDUSTRIALS if the company operates in Industrials sector and 0, otherwise; TECHNOLOGY if the company operates in Technology sector and 0, otherwise; TELECOMMUNICATION SERVICES if the company operates in Telecommunication Services sector and 0 , otherwise; UTILITIES if the company operates in Utilities sector and 0 , otherwise. 
Table 5

Correlation matrix

\begin{tabular}{|c|c|c|c|c|c|c|c|c|c|c|c|c|c|c|c|c|c|c|c|}
\hline & $\mathrm{VIF}$ & (1) & (2) & (3) & (4) & (5) & (6) & (7) & (8) & (9) & (10) & (11) & (12) & (13) & (14) & (15) & (16) & (17) & (18) \\
\hline CSR_DISC (1) & 1.41 & 1 & & & & & & & & & & & & & & & & & \\
\hline B_SPECI_SKILLS (2) & 1.13 & $-0.126 * * *$ & 1 & & & & & & & & & & & & & & & & \\
\hline WBOARD (3) & 1.28 & $0.207 * * *$ & $-0.310^{* * * *}$ & 1 & & & & & & & & & & & & & & & \\
\hline CG_COMMT (4) & 1.64 & $-0.119 * * *$ & $-0.092 * * *$ & $0.244 * * *$ & 1 & & & & & & & & & & & & & & \\
\hline LME (5) & 1.77 & $-0.248 * * *$ & $-0.075^{* * * *}$ & $0.263 * * *$ & $0.540 * * *$ & 1 & & & & & & & & & & & & & \\
\hline BODSIZE (6) & 1.27 & 0.356 *** & $-0.132 * * *$ & $0.135^{* * * *}$ & $0.144 * * *$ & $-0.061 * * *$ & 1 & & & & & & & & & & & & \\
\hline SIZE (7) & 1.12 & $0.550^{* * * *}$ & $0.128 * * *$ & $0.143 * * *$ & $0.124 * * *$ & $-0.149 * * *$ & $0.550^{* * * *}$ & 1 & & & & & & & & & & & \\
\hline Q_TOBIN (8) & 1.11 & 0.000 & $-0.042 * * *$ & $0.031 * *$ & $-0.206 * * *$ & $0.028 *$ & $-0.030^{*}$ & $-0.024 * *$ & 1 & & & & & & & & & & \\
\hline CEO_POW (9) & 1.11 & $0.082 * * *$ & $0.044 * * *$ & -0.021 & 0.091 & $0.264 * * *$ & -0.008 & $-0.035 * * *$ & $0.027 * * *$ & 1 & & & & & & & & & \\
\hline LEVERAGE (10) & 1.01 & $0.142 * * *$ & $-0.090^{* * * *}$ & $0.070^{* * * *}$ & $-0.023 * *$ & $-0.042 * * *$ & $0.182^{* * * *}$ & $0.278 * * *$ & $0.689^{* * * *}$ & $-0.028 *$ & 1 & & & & & & & & \\
\hline BASIC MATERIALS (11) & 2.00 & $0.046 * * *$ & -0.003 & $-0.087 * * *$ & $-0.070 * * *$ & $-0.022^{* * *}$ & $-0.069 * * *$ & $-0.065 * * *$ & $-0.049 * * *$ & $-0.035 * * *$ & $-0.054 * * *$ & 1 & & & & & & & \\
\hline CONSUMER CYCLICAL (12) & 2.71 & $-0.076 * * * *$ & $-0.029 * *$ & $0.036^{* * * *}$ & $-0.032 * * *$ & $0.050^{* * * *}$ & -0.008 & $-0.071 * * *$ & 0.016 & $0.032^{* * *}$ & $-0.020 * *$ & $-0.199 * * *$ & 1 & & & & & & \\
\hline $\begin{array}{l}\text { CONSUMER NON- } \\
\text { CYCLICAL (13) }\end{array}$ & 1.51 & $0.095 * * *$ & $-0.074 * * *$ & $0.145 * * *$ & $-0.002 * * *$ & $0.025 * *$ & $0.082 * * *$ & $0.048 * * *$ & $0.049 * * *$ & -0.002 & $0.074 * * *$ & $-0.133 * * *$ & $-0.166 * * *$ & 1 & & & & & \\
\hline ENERGY(14) & 1.41 & $-0.097 * * *$ & $0.092 * * *$ & $-0.060^{* * * *}$ & $0.158 * * *$ & $0.116^{* * * *}$ & $-0.034 * * *$ & $0.037 * * *$ & $-0.148 * * * *$ & $-0.049 * * *$ & $-0.090 * * *$ & $-0.123 * * *$ & $-0.154 * * *$ & $-0.103 * * *$ & 1 & & & & \\
\hline HEALTHCARE (15) & 1.39 & $-0.043 * * *$ & -0.021 ** & $0.037 * * *$ & $0.037 * * *$ & $-0.026 * * *$ & $-0.057 * * *$ & $-0.051 * * *$ & $-0.131 * * *$ & 0.013 & $-0.089 * * *$ & $-0.125 * * *$ & $-0.156 * * *$ & $0.104 * * *$ & $-0.096 * * *$ & 1 & & & \\
\hline INDUSTRIALS(16) & 2.83 & $0.031 * *$ & 0.005 & $-0.107 * * *$ & $-0.139^{* * * *}$ & $-0.129 * * *$ & $0.041 * * *$ & 0.006 & $0.171 * * *$ & $0.025 * *$ & $0.111 * * *$ & $-0.210^{* * * *}$ & $-0.262 * * *$ & $-0.175^{* * * *}$ & $-0.162 * * *$ & $-0.164 * * * *$ & 1 & & \\
\hline TECHNOLOGY(17) & 1.38 & 0.005 & $0.097 * * *$ & $-0.036 * * *$ & $0.074 * * *$ & $-0.022^{* * *}$ & $0.074 * * *$ & $-0.049 * * *$ & $-0.137 * * *$ & $0.049 * * *$ & $-0.221 * * *$ & $-0.124 * * * *$ & $-0.154 * * *$ & $-0.103 * * * *$ & $-0.095 * * *$ & $-0.097 * * *$ & $-0.163^{* * * *}$ & 1 & \\
\hline $\begin{array}{l}\text { TELECOMMUNICATION } \\
\text { SERVICES (18) }\end{array}$ & 5.37 & 0.010 & $-0.018^{*}$ & $0.058^{* * * *}$ & 0.000 & $-0.019^{* * *}$ & $0.055^{* * * *}$ & $0.0963 * * *$ & $0.079 * * *$ & $-0.048 * * *$ & $0.113 * * *$ & $-0.0734 * * *$ & $-0.092^{* * * *}$ & $-0.062^{* * * *}$ & $-0.057^{* * * *}$ & $-0.058 * * * *$ & $-0.097 * * *$ & $-0.057 * * *$ & 1 \\
\hline UTILITIES (19) & 8.36 & $0.045 * * *$ & $-0.056 * * * *$ & $0.101 * * *$ & $0.087 * * *$ & $0.082 * * *$ & $0.102 * * * *$ & $0.157 * * *$ & $0.133 * * *$ & $-0.023 * *$ & $0.236 * * *$ & $-0.092 * * *$ & $-0.116 * * * *$ & $-0.077 * * *$ & $-0.071^{* * * *}$ & $-0.073 * * *$ & $-0.122 * * * *$ & $-0.072 * * *$ & $-0.043 * * *$ \\
\hline
\end{tabular}

Correlation matrix. CSR_DISC is calculated as the aggregation of 112 items concerning social and environmental issues; B_SPECI_SKILLS is mesuread as the percentage of board members who have an industryspecific background; WBOARD is calculated as the proportion of female directors on boards; CG_COMMT is calculated as dummy variable that takes the value 1 if the firm has a Corporate Governance Committee and 0 , otherwise; LME is measured as a dummy variable that takes the value 1 if the country operates in a liberal market economy and 0 , if the country operates in a coordinated market economy; BODSIZE is the total number of dis CEO, CEO, which is a dis takes the value 1 CEO board and 0 , Othewwise, SIZE is the log or total sales, LEVERAGE is the debt over total assets, BASIC MATERIALS if the company operates in Basic Materials sector and 0, otherwise, CONSUMER CYCLICALS if the company operates in Consumer Cyclicals sector and 0, otherwise; CONSUMER NON-CYCLICALS if the company operates in Consumer Non-Cyclicals sector and 0, otherwise; ENERGY if the company operates 
in Energy sector and 0, otherwise; HEALTHCARE if the company operates in Healthcare sector and 0, otherwise; INDUSTRIALS if the company operates in Industrials sector and 0, otherwise; TECHNOLOGY if the company operates in Technology sector and 0, otherwise; TELECOMMUNICATION SERVICES if the company operates in Telecommunication Services sector and 0, otherwise; UTILITIES if the company operates in Utilities sector and 0 , otherwise. ${ }^{*}$-value $<0.1 * *$ p-value $<0.05 * *$ p-value $<0.01$ 
Table 6

Results of the Generalized Method of Moments

\begin{tabular}{|c|c|c|c|c|}
\hline & $\begin{array}{c}\text { MODEL 1 } \\
\text { D.V.= CSR_DISC } \\
\text { Coef. } \\
\text { (P.value) }\end{array}$ & $\begin{array}{c}\text { MODEL 2 } \\
\text { D.V.= B_SPECI_SKILLS } \\
\text { Coef. } \\
\text { (P.value) }\end{array}$ & $\begin{array}{c}\text { MODE 3 } \\
\text { D.V.= WBOARD } \\
\text { Coef. } \\
\text { (P.value) }\end{array}$ & $\begin{array}{c}\text { MODEL 4 } \\
\text { D.V.= CG_COMMT } \\
\text { Coef. } \\
\text { (P.value) }\end{array}$ \\
\hline CSR_DIS(t-1) & $\begin{array}{c}0.152 \\
(0.795)\end{array}$ & & & \\
\hline B_SPECI_SKILLS (t-1) & & $\begin{array}{c}0.273 * * * \\
(0.000)\end{array}$ & & \\
\hline WBOARD (t-1) & & & $\begin{array}{c}0.750 * * * \\
(0.000)\end{array}$ & \\
\hline CG_COMMT (t-1) & & & & $\begin{array}{c}0.706 * * * \\
(0.000)\end{array}$ \\
\hline LME & $\begin{array}{l}54.258 \\
(0.158)\end{array}$ & $\begin{array}{c}-38.127 * * \\
(0.030)\end{array}$ & $\begin{array}{l}7.052 * * \\
(0.028)\end{array}$ & $\begin{array}{c}0.358 * * * \\
(0.004)\end{array}$ \\
\hline BODSIZE & $\begin{array}{c}2.628 \\
(0.227)\end{array}$ & $\begin{array}{l}-2.104 \\
(0.570)\end{array}$ & $\begin{array}{l}-0.137 \\
(0.821)\end{array}$ & $\begin{array}{l}-0.002 \\
(0.871)\end{array}$ \\
\hline Q_TOBIN & $\begin{array}{l}-2.039 \\
(0.796)\end{array}$ & $\begin{array}{l}-33.371 \\
(0.214)\end{array}$ & $\begin{array}{l}-3.137 \\
(0.376)\end{array}$ & $\begin{array}{c}0.215 \\
(0.104)\end{array}$ \\
\hline CEO_POW & $\begin{array}{c}2.471 \\
(0.369)\end{array}$ & $\begin{array}{l}8.412^{*} \\
(0.065)\end{array}$ & $\begin{array}{c}1.437 \\
(0.186)\end{array}$ & $\begin{array}{c}0.034 \\
(0.479)\end{array}$ \\
\hline SIZE & $\begin{array}{c}2.506 \\
(0.190)\end{array}$ & $\begin{array}{c}1.901 \\
(0.738)\end{array}$ & $\begin{array}{c}0.080 \\
(0.610)\end{array}$ & $\begin{array}{c}0.015 \\
(0.755)\end{array}$ \\
\hline LEVERAGE & $\begin{array}{l}-0.008^{*} \\
(0.050)\end{array}$ & $\begin{array}{l}-0.001 \\
(0.977)\end{array}$ & $\begin{array}{c}0.001 \\
(0.762)\end{array}$ & $\begin{array}{c}0.000 \\
(0.703)\end{array}$ \\
\hline BASIC MATERIALS & $\begin{array}{c}206.138 \\
(0.440)\end{array}$ & $\begin{array}{c}-109.526 \\
(0.248)\end{array}$ & $\begin{array}{c}-2.713 * \\
(0.066)\end{array}$ & $\begin{array}{c}-0.018 \\
(0.764)\end{array}$ \\
\hline CONSUMER CYCLICAL & $\begin{array}{l}194.337 \\
(0.474)\end{array}$ & $\begin{array}{c}-106.021 \\
(0.264)\end{array}$ & $\begin{array}{c}-2.547 * * \\
(0.049)\end{array}$ & $\begin{array}{l}-0.023 \\
(0.694)\end{array}$ \\
\hline CONSUMER NON-CYCLICAL & $\begin{array}{c}262.258 \\
(0.388)\end{array}$ & $\begin{array}{c}-107.675 \\
(0.256)\end{array}$ & $\begin{array}{l}-1.117 \\
(0.273)\end{array}$ & $\begin{array}{l}-0.023 \\
(0.629)\end{array}$ \\
\hline ENERGY & $\begin{array}{l}60.150 \\
(0.780)\end{array}$ & $\begin{array}{c}-101.751 \\
(0.292)\end{array}$ & $\begin{array}{c}-4.270 * * \\
(0.036)\end{array}$ & $\begin{array}{c}0.026 \\
(0.659)\end{array}$ \\
\hline HEALTHCARE & $\begin{array}{l}81.403 \\
(0.740)\end{array}$ & $\begin{array}{c}-114.196 \\
(0.237)\end{array}$ & $\begin{array}{c}-1.988 \\
(0.247)\end{array}$ & $\begin{array}{c}0.059 \\
(0.347)\end{array}$ \\
\hline INDUSTRIALS & $\begin{array}{c}237.583 \\
(0.531)\end{array}$ & $\begin{array}{c}-113.499 \\
(0.233)\end{array}$ & $\begin{array}{c}-1.986^{* * *} \\
(0.039)\end{array}$ & $\begin{array}{l}-0.015 \\
(0.749)\end{array}$ \\
\hline TECHNOLOGY & $\begin{array}{c}214.382 \\
(0.546)\end{array}$ & $\begin{array}{c}-121.789 \\
(0.288)\end{array}$ & $\begin{array}{l}-2.729 \\
(0.132)\end{array}$ & $\begin{array}{c}0.070 \\
(0.224)\end{array}$ \\
\hline UTILITIES & -82.420 & -124.316 & $-2.074 *$ & -0.024 \\
\hline
\end{tabular}


$(0.603)$

Yes

Year effect

Arellano-Bond test AR(1) (z, p > $>\mathbf{z} \mid)$

Arellano-Bond test AR(2) (z, p>|z|)

Hansen test (Chi-square, $p>\left|\mathbf{C h i}^{2}\right|$ )

Number of instrumental variables

Observations

$-3.51(0.000)$

$0.44(0.663)$

$20.27(0.208)$

41

8,496
Yes

$-7.12(0.000)$

$-0.05(0.961)$

$18.80(0.101)$

37
(0.083)

Yes

$-15.58(0.000)$

$0.38(0.700)$

$18.49(0.358)$
Yes

$-4.69(0.000)$

$-1.33(0.182)$

$14.04(0.596)$

41

All models have been estimated by two-step and system GMM estimator with robust standard errors. CSR_DISC is calculated as the aggregation of 112 items concerning social and environmental issues; B_SPECI_SKILLS is mesuread as the percentage of board members who have an industry-specific background; WBOARD is calculated as the proportion of female directors on boards; CG_COMMT is calculated as dummy variable that takes the value 1 if the firm has a Corporate Governance Committee and 0 , otherwise; LME is measured as a dummy variable that takes the value 1 if the country operates in a liberal market economy and 0 , if the country operates in a coordinated market economy; BODSIZE is the total number of directors on boards; Q TOBIN is calculated as the market capitalization of common stock+ book value liabilities divided by the book value of total assets; CEO_POW is measured as the aggregation of four dummies variables: (1) Ceo duality,which is a dummy variable that takes the value 1 if the same person serves simultaneously as CEO and chairman of the board and 0 , otherwise, (2) the Chairman of the board is ex-CEO, which is a dummy variable that takes the value 1 if the chairman of the board held the CEO position in the company prior to becoming chairman and 0, otherwise, (3) CEO tenure, which is a dummy variable that takes the value 1 if CEO tenure is above the sample median and 0 , otherwise and (4) CEO board member, which is a dummy variable that takes the value 1 if the CEO serves as a board member, but not as chair of the board and 0, otherwise; SIZE is the log of total sales; LEVERAGE is the debt over total assets; BASIC MATERIALS if the company operates in Basic Materials sector and 0, otherwise; CONSUMER CYCLICALS if the company operates in Consumer Cyclicals sector and 0, otherwise; CONSUMER NON-CYCLICALS if the company operates in Consumer Non-Cyclicals sector and 0, otherwise; ENERGY if the company operates in Energy sector and 0 , otherwise; HEALTHCARE if the company operates in Healthcare sector and 0 , otherwise; INDUSTRIALS if the company operates in Industrials sector and 0, otherwise; TECHNOLOGY if the company operates in Technology sector and 0, otherwise; TELECOMMUNICATION SERVICES if the company operates in Telecommunication Services sector and 0 , otherwise; UTILITIES if the company operates in Utilities sector and 0 , otherwise. D.V.= Dependent variable. ${ }^{*}$ p-value $<0.1 * *$ p-value $<0.05 * * *$ pcompany op
value $<0.01$. 
Table 7

Results of the firm fixed-effects panel data regressions

\begin{tabular}{|c|c|c|c|c|}
\hline & $\begin{array}{c}\text { MODEL 1 } \\
\text { D.V.=CSR_DISC } \\
\text { Coef. } \\
\text { (P.value) }\end{array}$ & $\begin{array}{c}\text { MODEL 2 } \\
\text { D.V.=B_SPECI_SKI } \\
\text { LLS } \\
\text { Coef. } \\
\text { (P.value) }\end{array}$ & $\begin{array}{c}\text { MODE 3 } \\
\text { D.V.= } \\
\text { WBOARD } \\
\text { Coef. } \\
\text { (P.value) }\end{array}$ & $\begin{array}{c}\text { MODEL 4 } \\
\text { D.V.=CG_COM } \\
\text { MT } \\
\text { Coef. } \\
\text { (P.value) }\end{array}$ \\
\hline \multirow[t]{2}{*}{ LME } & 0.012 & $-0.431^{*}$ & $0.246^{* * *}$ & $0.007 * * *$ \\
\hline & $(0.900)$ & $(0.085)$ & $(0.007)$ & $(0.001)$ \\
\hline \multirow[t]{2}{*}{ BODSIZE } & $0.103 *$ & $-0.303 *$ & -0.023 & $0.003 * *$ \\
\hline & $(0.096)$ & $(0.099)$ & $(0.701)$ & $(0.010)$ \\
\hline \multirow[t]{2}{*}{ Q_TOBIN } & 0.217 & 1.049 & -0.209 & 0.007 \\
\hline & $(0.219)$ & $(0.217)$ & $(0.159)$ & $(0.130)$ \\
\hline \multirow[t]{2}{*}{ CEO_POW } & -0.204 & 0.855 & -0.090 & -0.011 \\
\hline & $(0.501)$ & $(0.261)$ & $(0.727)$ & $(0.153)$ \\
\hline \multirow[t]{2}{*}{ SIZE } & 0.024 & 0.124 & -0.062 & 0.015 \\
\hline & $(0.612)$ & $(0.427)$ & $(0.160)$ & $(0.407)$ \\
\hline \multirow[t]{2}{*}{ LEVERAGE } & -0.000 & -0.000 & 0.000 & 0.000 \\
\hline & $(0.542)$ & $(0.627)$ & $(0.183)$ & $(0.000)$ \\
\hline \multirow[t]{2}{*}{ BASIC MATERIALS } & 0.199 & 0.418 & 0.183 & $0.007 *$ \\
\hline & $(0.200)$ & $(0.242)$ & $(0.181)$ & $(0.067)$ \\
\hline \multirow[t]{2}{*}{ CONSUMER CYCLICAL } & $-0.355^{* *}$ & -0.065 & $-0.207 *$ & 0.003 \\
\hline & $(0.010)$ & $(0.843)$ & $(0.080)$ & $(0.184)$ \\
\hline CONSUMER NON- & $0.297^{*}$ & -0.562 & 0.105 & 0.002 \\
\hline CYCLICAL & $(0.097)$ & $(0.153)$ & $(0.522)$ & $(0.550)$ \\
\hline \multirow[t]{2}{*}{ ENERGY } & $-0.543 * * *$ & $-0.718^{*}$ & -0.108 & -0.006 \\
\hline & $(0.002)$ & $(0.064)$ & $(0.447)$ & $(0.162)$ \\
\hline \multirow[t]{2}{*}{ HEALTHCARE } & -0.027 & -0.654 & -0.039 & $0.009 * *$ \\
\hline & $(0.871)$ & $(0.102)$ & $(0.812)$ & $(0.025)$ \\
\hline \multirow[t]{2}{*}{ INDUSTRIALS } & 0.113 & -0.691 & 0.311 & 0.011 \\
\hline & $(0.602)$ & $(0.430)$ & $(0.222)$ & $(0.120)$ \\
\hline \multirow[t]{2}{*}{ TECHNOLOGY } & -0.059 & -0.503 & -0.024 & 0.002 \\
\hline & $(0.734)$ & $(0.109)$ & $(0.876)$ & $(0.424)$ \\
\hline \multirow[t]{2}{*}{ UTILITIES } & $-.457 * *$ & 0.211 & $-0.040 * * *$ & -0.002 \\
\hline & $(0.026)$ & $(0.641)$ & $(0.000)$ & $(0.353)$ \\
\hline Firm fixed effects & Yes & Yes & Yes & Yes \\
\hline Year effects & Yes & Yes & Yes & Yes \\
\hline $\mathrm{R}^{2}$ & $68.88 \%$ & $4.51 \%$ & $21.48 \%$ & $3.06 \%$ \\
\hline Observations & 10,043 & 10,043 & 10,043 & 10,043 \\
\hline
\end{tabular}

All models have been estimated with robust standard errors. CSR DISC is calculated as the aggregation of 112 items concerning social and environmental issues; B_SPECI_SKILLS is mesuread as the percentage of board members who have an industry-specific background; WBOARD is calculated as the proportion of female directors on boards; CG COMMT is calculated as dummy variable that takes the value 1 if the firm has a Corporate Governance Committee and 0, otherwise; LME is measured as a dummy variable that takes the value 1 if the country operates in a liberal market economy and 0 , if the country operates in a coordinated market economy; BODSIZE is the total number of directors on boards; Q TOBIN is calculated as the market capitalization of common stock+ book value liabilities divided by the book value of total assets; CEO_POW is measured as the aggregation of four dummies variables: (1) Ceo duality,which is a dummy variable that takes the value 1 if the same person serves simultaneously as CEO and chairman of the board and 0, otherwise, (2) the Chairman of the board is ex-CEO, which is a dummy variable that takes the value 1 if the chairman of the board held the CEO position in the company prior to becoming chairman and 0 , otherwise, (3) CEO tenure, which is a dummy variable that takes the value 1 if CEO tenure is above the sample median and 0 , otherwise and (4) CEO board member, which is a dummy variable that takes the value 1 if the CEO serves as a board member, but not as chair of the board and 0, otherwise; SIZE is the log of total sales; LEVERAGE is the debt over total assets; BASIC MATERIALS if the company operates in Basic Materials sector and 0, otherwise; CONSUMER CYCLICALS if the company operates in Consumer Cyclicals sector and 0, otherwise; CONSUMER NON-CYCLICALS if the company operates in Consumer Non-Cyclicals sector and 0, otherwise; ENERGY if the company operates in Energy sector and 0, otherwise; HEALTHCARE if the company operates in Healthcare sector and 0, otherwise; INDUSTRIALS if the company operates in Industrials sector and 0, otherwise; TECHNOLOGY if the company operates in Technology sector and 0, otherwise; TELECOMMUNICATION SERVICES if the company operates in Telecommunication Services sector and 0 , otherwise; UTILITIES if the company operates in Utilities sector and 0 , otherwise. D.V.= Dependent variable. ${ }^{*}$ pvalue $<0.1 * *$ p-value $<0.05 * * *$ p-value $<0.01$. 